\title{
Pentingnya Menerapkan Materi Lingkungan \\ Dalam Pembelajaran Bahasa Indonesia
}

\section{Oleh: Diratul Afifah}

diraafifah@gmail.com

Ramadhan, Sukma, dan Indriyani (2019) mengatakan peningkatan kesadaran tentang lingkungan dapat diperoleh melalui proses pendidikan. Pendidikan merupakan elemen kunci dalam pencegahan dan resolusi masalah lingkungan. Sukma, Ramadhan, dan Indriyani (2020) mengatakan peran penting pendidikan lingkungan adalah mengembangkan individu yang memiliki pengetahuan ilmiah tentang masalah lingkungan dan kepedulian lingkungan yang tinggi. Selain itu, berpotensi membantu generasi penerus mengelola kehidupan dan membangun masa depan yang sejahtera.

Pada saat ini permasalahan lingkungan dari masa-kemasa terus bertambah, hal itu disebabkan oleh banyaknya peristiwa-peristiwa yang terjadi, baik dari kesalahan manusia itu sendiri maupun dari gejala alam. Kerusakan tersebut berdampak buruk bagi kelangsungan makhluk hidup.

Salah satu upaya yang dilakukan untuk menanggulangi masalah tentang lingkungan yaitu dengan menanamkan sikap peduli lingkungan mulai dari sejak dini kepada generasi muda sekarang. Langkah awal yang dilakukan untuk penanggulangan hal tersebut dengan membuang sampah pada tempatnya, menggunakan air secukupya dan lain sebagainya.

Angin, Ramadhan, dan Agustina (2015) mengatakan menggunakan materi lingkungan membuat siswa lebih peka terhadap lingkungannya karena dapat menyajikan hasil pengamatannya. Menurut Sukma dan Sihes (2016) proses pembelajaran di sekolah dasar diciptakan dengan suasana yang kondusif dan menyenangkan. Proses pembelajaran adalah proses interaksi peserta didik dan sumber belajar pada suatu lingkungan belajar. Menurut Fitri, Ramadhan dan Tamsin (2016) mengatakan pembelajaran merupakan suatu pembelajaran yang menggabungkan kemampuan berpikir, berbicara, dan menulis siswa.

Sukma, Ramadhan, dan Indriyani (2020) mengatakan pendidikan lingkungan merupakan upaya bersama yang diselenggarakan secara sadar untuk mengajarkan atau menarik perhatian manusia tentang bagaimana lingkungan alam berfungsi dan bagaimana manusia tersebut dapat mengelola dan melindunginya.

Hartidini, Ramadhan, dan Ratna (2018) mengatakan rendahnya mutu atau kualitas pembelajaran bahasa dan sastra Indonesia di sekolah selama ini disebabkan oleh hal seperti, metode belajar yang diterapkan oleh guru, minat siswa dalam pembelajaran, dan masih banyak hal lainnya. Wasillah, Ramadhan, dan Noveria (2016) mengatakan pembelajaran bahasa juga 
dapat meningkatkan keterampilan berbahasa, memperluas wawasan, dan mendorong siswa untuk memiliki kemampuan bersastra yang komunikatif.

Radesi (dalam Sari, Ramadhan, dan Rasyid 2018) mengatakan guru adalah komponen yang sangat menentukan dalam implementasi suatu strategi dalam mengefektifkan proses pembelajaran. Keberhasilan implementasi suatu strategi pembelajaran tergantung pada kepiawaian guru dalam menggunakan metode, teknik dan taktik mengajarnya. Menurut Sukma dan Dania (2020) mengatakan guru juga perlu menguasai metode pembelajaran, agar dapat melaksanakan pembelajaran yang menyenangkan. Penilaian pembelajaran perlu dikuasai untuk memperoleh informasi tentang pencapaian belajar siswa. Menurut Sukma (2007) mengatakan guru berperan penting untuk mengembangkan pengetahuan dan pengalaman siswa dalam kehidupan sehari-hari, serta membimbing siswa ke arah berpikir kritis terhadap hal-hal yang berkaitan dengan pengalaman siswa.

Berdasarkan permasalahan yang dijabarkan di atas, penulis melakukan penelitian mengenai "Pentingnya Menerapkan Materi Lingkungan Dalam Pembelajaran Bahasa Indonesia" yang dibagikan kepada mahasiswa sebanyak 47 orang seperti STIE Haji Agus Salim Bukittinggi, UIN Medan, Universitas Andalas, Universitas Perintis Indonesia, SUPM Pariaman, TQ Babul Jannah, UIN Syarif Hidayatullah Jakarta, Universitas Diponegoro, Universitas Padjadjaran, dan Universitas Negeri Padang yang wajib mencantumkan jenis kelamin dan pekerjaan. Dari jumlah keseluruhan responden yang mengisi angket, ternyata perempuan lebih dominan dibandingkan dengan laki-laki, dengan persentasi 89,4\% perempuan dan 10,6\% laki-laki. Penelitian ini menggunakan google form, penulis memberikan 10 pertanyaan yang wajib diisi oleh responden. Hasil yang didapat dari penelitian ini adalah sebagai berikut. Pertanyaan pertama, yaitu materi lingkungan perlu dimasukkan ke dalam pembelajaran bahasa Indonesia menyatakan sangat setuju 42,6\%, 55,3\% menyatakan setuju, 2,1\% menyatakan kurang setuju dan $0 \%$ menyatakan tidak setuju. Pertanyaan kedua, yaitu materi lingkungan berperan penting dalam proses pembelajaran bahasa Indonesia menyatakan sangat setuju 27,7\%, 70,2\% menyatakan setuju, 2,1\% menyatakan kurang setuju dan 0\% menyatakan tidak setuju. Pertanyaan ketiga, yaitu guru menugaskan siswa untuk menonton film tentang cara mendaur ulang sampah. Ketika, belajar lebih memudahkaan siswa untuk membuat teks ulasan ulang menyatakan sangat setuju 36,2\%, 6,4\% menyatakan kurang setuju, dan 2,1\% menyakan tidak setuju. Pertanyaan keempat, yaitu pembelajaran bahasa Indonesia berkaitan dengan lingkungan sosial, lingkungan alam, dan lingkungan hidup menyatakan sangat setuju 42,6\%, 57,4\% menyatakan setuju, 0\% menyatakan kurang setuju dan 0\% menyatakan tidak setuju. Pertanyaan kelima, yaitu siswa yang menggunakan bahasa Indonesia 
sebagai bahasa pertama akan berpengaruh terhadap cara berbicaranya saat di sekolah menyatakan sangat setuju 46,8\%, 48,9\% menyatakan setuju, $4.3 \%$ menyatakan kurang setuju dan $0 \%$ menyatakan tidak setuju. Pertanyaan keenam, yaitu materi lingkungan dapat meningkatkan kemampuan kreativitas siswa dalam pembelajaran bahasa Indonesia menyatakan sangat setuju 38,3\%, 61,7\% menyatakan setuju, $0 \%$ menyatakan kurang setuju dan 0\% menyatakan tidak setuju. Pertanyaan ketujuh, yaitu materi lingkungan merupakan salah satu media pembelajaran bahasa Indonesia yang sangat dianjurkan menyatakan sangat setuju $25,5 \%, 72,3 \%$ menyatakan setuju, 2,1\% menyatakan kurang setuju dan $0 \%$ menyatakan tidak setuju. Pertanyaan kedelapan, yaitu pembelajaran bahasa Indonesia membuat siswa lebih memperhatikan lingkungan sekitar menyatakan sangat setuju 31,9\%, 63,8\% menyatakan setuju, 4,3\% menyatakan kurang setuju dan 0\% menyatakan tidak setuju. Pertanyaan kesembilan, yaitu materi lingkungan meningkatkan semangat siswa dalam mempelajari bahasa Indonesia. Contoh dari materinya (teks deskripstif, teks narasi, dan lain-lain) dapat dilihat dari lingkungan sekitar sekolah menyatakan sangat setuju 31,9\%, 68,1\% menyatakan setuju, 0\% menyatakan kurang setuju dan 0\% menyatakan tidak setuju. Pertanyaan terakhir, yaitu membiasakan penggunaan bahasa Indonesia pada lingkungan sekolah akan membantu siswa menjadi terbiasa dalam pembelajaran bahasa Indonesia menyatakan sangat setuju 53,2\%, 46,8\% menyatakan setuju, $0 \%$ menyatakan kurang setuju dan $0 \%$ menyatakan tidak setuju.

Dari hasil penelitian penulis diatas, dapat disimpulkan bahwa materi lingkungan sangat penting untuk diterapkan dalam pembelajaran bahasa Indonesia. Oleh karena itu, dengan materi lingkungan guru bisa dengan mudah mencari contoh relevan yang membuat siswa lebih memahami materi yang diberikan, sehingga dapat membantu guru dalam mengimplikasikan materi bahasa Indinesia di sekolah. Lembaga pendidikan memiliki peran penting dalam proses penanaman pendidikan wawasan lingkungan kepada peserta didik, dan pendidik senantiasa menjadi penyambung proses nilai-nilai positif berbasis lingkungan kepada peserta didik. Hal ini sesuai dengan pendapat Hauchild S, Poltavthenko E, dan Stoller F, L (dalam Ramadhan et al, 2019), dengan mengintegrasikan pendidikan lingkungan ke dalam kelas, guru dapat meningkatkan minat siswa terhadap permasalahan konteporer yang mengkin langsung mempengaruhi masa depan mereka. 


\section{Daftar Pustaka:}

Angin, Toras Barita Bayo, Ramadhan, Syahrul, Agustina. (2015). Berbasis Pendekatan Kontekstual Pada Menulis Iklan Di Kelas VIII Smp 2 Padangsidimpuan Sumatera Utara. Jurnal Bahasa, Sastra, dan Pembelajaran. 3(1); 27-31.

Dania, Rama, Sukma, Elfia. (2020). Peningkatan Proses Pembelajaran Tematik Terpadu Menggunakan Model Cooperative Learning Tipe Talking Stick di SD. Jurnal Pendidikan Tambusai. 4(3); 2624-2626

Fitri, Yulia, R, Syahrul, Tamsin, Andria Catri. (2016). Pengaruh model pembelajaran kooperatif tipe think talk write berbantuan media gambar berseri terhadap keterampilan menulis teks cerpen siswa kelas VII SMP Negeri 8 Padang. Jurnal Pendidikan Bahasa dan Sastra Indonesia, 5(2); 548-551.

Hartidini, Suci, Syahrul Ramadhan, Ratna, Ellya. (2018). Pengaruh Strategi Pembelajaran Inkuiri Berbantuan Media Audiovisual Terhadap Keterampilan Menulis Karangan Argumentasi Siswa Kelas X Sma Negeri 2 Lengayang Kabupaten Pesisir Selatan. Jurnal Pendidikan Bahasa dan Sastra Indonesia. 1(7); 63-66.

Ramadhan, S, Sukma, E, dan Indriyani, V. 2019. Environmental education and disaster mitigation through language learning. IOP Conference Series: Earth and Environmental Science. 314(1): 1-9

Sari, Yuliana, Ramadhan, Syahrul, Rasyid, Yulianti. Hubungan Antara Keterampilan Membaca Pemahaman Dengan Keterampilan Menulis Teks Laporan Hasil Observasi Siswa Kelas X Smk Negeri 3 Padang. Jurnal Pendidikan Bahasa dan Sastra Indonesia. $7(3) ; 446-448$.

Sukma, Elfia, Sihes, Ahmad Johari. (2015). Kompetensi Kognitif Pembelajaran Apresiasi Sastra Di Sekolah Dasar. Jurnal Gramatika. 1(2); 1-3

Sukma, Elfia. (2015). Peningkatan Kemampuan Menulis Puisi Siswa Kelas V Sd Negeri Sumbersari III Malang Dengan Strategi Pemetaan Pikiran. Jurnal Diksi. 14(1); 38-40.

Sukma, E, Ramadhan, S, Indriyani, V. 2020. Integration of environmental education in elementary schools. Journal of Physics: Conference Series.1481(1): 1-2

Wasilah, Tri, R., Syahrul, Noveria, Ena. (2016). Pengaruh Model Pembelajaran Kooperatif Tipe Think Pair Share terhadap Keterampilan Menulis Naskah Drama Satu Babak Siswa Kelas VIII SMP Negeri 30 Padang. Jurnal Pendidikan Bahasa dan Sastra Indonesia. 5(1); 8-10. 